\title{
Evaluation of Prophet Muhammad's Techniques in Managing Misbehaviors: Application in Primary School Classrooms
}

\author{
Wan Mazwati Wan Yusoff \\ International Islamic University Malaysia \\ wanmazwati@iium.edu.my \\ Asyraff Hafdzan Abdullah \\ Islamic Science University Malaysia \\ asyraffdini@gmail.com
}

\section{Doi:10.5901/jesr.2015.v5n1s1p185}

\section{Abstract}

\begin{abstract}
Studies have shown that there is a correlation between troublesome classroom behaviors and a gamut of antisocial, aggressive-disruptive behaviors and psychiatric problems. Student classroom misbehavior is linked to student disengagement which correlates with alienation by peers and truancy. Students who misbehaved were reported to perform worse academically which escalated to other severe problems such as dropping out of school and delinquency. Researchers and academicians have designed and implemented intervention programs to reduce this problem. Good intervention program should meet the set criteria. This study aims to discover whether the techniques used by Prophet Muhammad in correcting mistakes of his companions could be applied in managing misbehaviors of primary school students during teaching and learning process; and to determine whether these techniques met the criteria of a good intervention program. Six relevant hadith on correcting mistakes were selected and analyzed to formulate techniques of managing misbehaviors which were implemented in two primary school classrooms by a trained teacher. This qualitative research examined and analysed journals written by the teacher; and the verbatim transcriptions of two one-hour interview sessions with the teacher to assess teacher's correct application of the techniques and to discover the impact of the techniques on students' behaviors. Findings revealed that the techniques used were effective in reducing classroom disruptive behaviors; easy to implement; not disrupting the normal classroom activities; and parsimonious. This study contributes to production of knowledge from Islamic worldview; and contributes to the relevantization project which is the mission of International Islamic University Malaysia.
\end{abstract}

Keywords: Classroom misbehaviors, classroom management, relevantization, hadith application, behavior management techniques

\section{Introduction}

Disruptive behavior is defined as "an activity that causes distress for teachers, interrupts the learning process, and activity that lead teachers to make continuous comments to the student" (Arbuckle \& Little, 2004: 60) or any "activities which disrupt and impede teaching and learning processes" (Thompson, 2009: 43). Most common classroom misbehaviors are being late for class; disengaged during teaching and learning process; talking out of turn; making distracting noises; arguing with other students; easily angered by others; losing temper; moving around the classroom unnecessarily; and disobeying teacher's instructions (Bowen, Jensen, \& Clark, 2004; Wakschlag, Leventhal, BriggsGowen, Danis, Keenan, \& Hill, 2005). Serious behavior problems occur less frequently but difficult to handle. Instances of serious misbehavior include stealing; fighting; bullying; and verbally abusing teachers and other students (Sullivan, Johnson, Owens, \& Conway, 2014). However, the pervasive classroom disruptive behaviors are mostly trivial and lowlevel disturbances. But, the loss of time and the difficulty to manage the misbehaviors have led teachers to stress and burnout. What is more, research findings have revealed that classroom behavior problem is a predictor for a myriad of social, behavioral, and psychiatric problems; such as antisocial behaviors, violence, high-risk sexual behavior, drug, alcohol, and tobacco abuse (Kellam, Brown, Poduska, lalongo, Wang, \& Toyinbo, 2008; Kellam, Mackenzie, Poduska, Wang, Petras \& Wilcox, 2011).

Teachers have applied strategies and techniques which they were familiar with to manage classroom misbehaviors. Some of the strategies used were to ensure student compliance by using punitive measures such as controlling students behaviors through negative and coercive interactions (Patterson, Reid, \& Dishion, 1992; Slee, 1995), 
referrals, suspensions, calling parents (Wakschlag, et al., 2005), more strict school rules (Way, 2011), reprimands and redirections (Madsen, Becker, \& Thomas, 2001; Wan Yusoff \& Mansor, 2014), sanctions (Kohn, 2006; Maguire, Ball, \& Braun, 2010), and disciplinary strategy through step system. This disciplinary strategy applies intensification of negative corrective measures beginning with, for instance, giving warning, in-class time out, out of class time out, redirection to a school leader, in-school suspension, out-of-school suspension, and the most extreme punishment is permanent exclusion from school (Raby, 2010). The assumption underpinnings step system is that when bad behavior is corrected, student learning will also be enhanced (Maguire, Ball, \& Braun, 2010). However, studies indicated that punitive measures and harsh punishment may create unruly, boisterous and disordered classroom environment (Madsen, Becker, \& Thomas, 2001); cause disobedience and rebelliousness among certain students (Way, 2011); reinforce student hostility and destructive behaviors (Rinke \& Herman, 2002); lead to negative outcomes including being dismissed by peers, academic failure, and further deterioration of antisocial behavior (Patterson, Reid, \& Dishion, 1992); and contribute to defiance and detachment, common misbehavior, and school violence (Angus et al., 2009). Even though studies have provided evidences against using punitive measures, however this practice is still prevalent especially in schools where teachers were not given formal training in pedagogy (Wan Yusoff \& Mansor, 2014).

The ineffectiveness of the strategies used and the detrimental effects of unresolved classroom misbehaviors have prompted researchers and academicians to develop and evaluate classroom behavior management strategies and intervention programs. Teacher could choose strategies that work for them and that have the following criteria: the strategies are effective, that is, they reduce and prevent the occurrence of disruptive behaviors; easy to implement, which means they would not require any structural changes and outside of school support, would not take much time to prepare, and can be easily accessible; the strategies used should not take much class time and disrupt the normal classroom activities (Guardino \& Fullerton, 2010; Cholewa, Smith-Adcock, \& Amatea, 2010); and cost effective.

Studies have shown that some evidence-based intervention programs were effective in reducing classroom disruptive behaviors and met the criteria of good intervention program. These intervention programs were evaluated by researches in a number of studies. Some examples of effective intervention programs are Good Behavior Game (Kellam et al., 2008; Kellam et al., 2011; Donaldson, Vollmer, Krous, Downs, \& Berard, 2011); Fast Track Program (CPPRG, 1999; CPPRG, 2002); Raising Healthy Children (Brown, Catalano, Fleming, Haggerty, \& Abbott, 2005; Hawkins, Kosterman, Catalano, Hill, \& Abbott, 2005); and The Incredible Years program (Webster-Stratton \& Hammond, 1997; Scott, Spender, Doolan, Jacobs, \& Aspland, 2001; Webster-Stratton et al., 2008). Research findings also confirmed various practical behavior management techniques such as general praise; behavior specific praise; and stating clear rules met the criteria of good strategies. These simple techniques were shown effective to promote student classroom engagement and may decrease disruptive classroom behaviors (Gable, Hester, Rock, \& Hughes, 2009; Henly, 2010; Kerr \& Nelson, 2010; Wheeler \& Richey, 2010; Pisacreta, Tincani, Connell, \& Axelrod, 2011; Wan Mazwati Wan Yusoff, 2012).

Even though these intervention programs were proven effective but they were never tested in Muslim settings. Perhaps these programs may be effective in Muslim settings as well, however human creativity prescribes that we should continue researching for different ways of solving problems. Those who are complacent and stop looking would lose the opportunity to find even better solutions. While evaluating the above mentioned programs, several questions arose. Such questions are: Are there simpler techniques and easier to implement? Are there techniques that can become second nature to teachers that they do not need to prepare? Are there techniques that blend well into the psyche of Muslims who are motivated by knowledge that comes out of Islamic worldview? Besides, good strategies and intervention program should cost the least but produce the best effect. But more importantly, taking into consideration cultural differences and Muslims' religious conviction that the Qur'an and Prophet Muhammad's Traditions (herein after would be referred to as hadith) are the two primary sources of knowledge which provide prescriptions for human behavioral problems, rigorous analysis of hadith for application in classroom settings were conducted. Equally significant, this research project is to realize the mission of International Islamic University Malaysia to make Islamic revealed knowledge "relevant to contemporary human and social issues and highly useful or indispensable for solving individual, social, national and international problems and issues" (Kamal Hasan, 2009: 120). Islamic revealed knowledge is knowledge that comes out of the Qur'an and Prophetic Tradition.

\subsection{Prophet's Methods of Handling Misbehaviors}

Prophet Muhammad is the archetype of perfect moral character who demonstrated to mankind the practical aspect of Islam. He set the precedent of excellent behavioral conduct which was followed by and become custom of Muslims 
across time and space. The doings and practices; verbal and nonverbal communication; and consent of Prophet Muhammad were reported and recorded in hadith. Hadith is replete with historical evidences which demonstrated that Prophet Muhammad had succeeded in motivating positive behavioral change among the Arabs at his time. This is further substantiated by the style of living of his companions which were also recorded in hadith literature. This means that data from hadith is full with strategies, methods, techniques, tools and procedures to promote good behavior. How to extract these from hadith is depended on how we frame the questions when we interact with hadith. The process of making hadith relevant to contemporary human and social issues involved continuous exegetical interpretation of the Qur'an and hadith (Ibrahim Zein, 2012).

The styles of living of Prophet Muhammad and his companions were a continuation of life before Islam except what have been delineated clearly by the Qur'an. The precedent of new tradition started when problems occurred and the Muslims went to the Prophet for guidance. Therefore, we can conclude that there are significant amount of hadith that dealt with how Prophet Muhammad handled various types of misbehaviours ranging from simple common mistakes committed by newcomers to Islam and grave mistakes committed by people of knowledge in Islam (al-Munajild, 2008). Besides, making mistakes is innate in human, however the best wrongdoers are those who repent (Ibn Majah, hadith no. 4251). This paper delimits its analysis on common mistakes relevant for application in primary school setting. We have selected six authentic hadith reported and authenticated by prominent scholars of hadith, namely Imam al-Bukhari (d. 870 A.D.) and Imam Muslim (d. 875 A.D.). Hadith is considered authentic when it met all the stringent criteria set by scholars of sciences of hadith. Sciences of Hadith is a vast field of knowledge which will not be discussed in this paper. Rigorous analysis of these six hadith revealed principles and techniques that can be applied to handle misbehaviors in classroom. The following section states and discusses the selected hadith.

\subsection{Dealing with Mistakes by Explaining the Rules}

Anas ibn Malik reported: "While we were in the mosque with the Messenger of Allah, a bedouin came and stood urinating in the mosque. The companions of the Messenger of Allah said, 'Mah! Mah! (harsh way of rebuking)' But the Messenger of Allah said, 'Do not interrupt him; leave him alone.' So they left him until he had finished urinating, then the Messenger of Allah called him and said, 'These mosques are not a place to throw any kind of filth, urinate or defecate; they are only for remembering Allah, praying and reading the Qur'an.' The he commanded a man who was there to bring a bucket of water and throw it over the urine, and he did so." Hadith number 285 recorded by Imam Muslim.

Mu'awiya ibn al-Hakam said: "While I was praying with the Messenger of Allah (may peace be upon him), a man sneezed. I said, 'Allah have mercy on you!' The people stared at me with disapproving looks, so I said, 'Woe be upon me, why is it that you stare at me?' They began to strike their hands on their thighs, and when I saw them urging me to observe silence (I became angry) but I said nothing. When the Messenger of Allah (may peace be upon him) had finished the prayer (and I declare that neither before him nor after him have I seen a leader who gave better instruction than he for whom I would give my father and mother as ransom). I swear that he did not scold, beat or revile me but said, 'Talking to persons is not fitting during the prayer; prayers are for glorifying Allah, declaring his Greatness and reciting the Qur'an or words to that effect." Hadith number 1094 recorded by Imam Muslim.

Two persons mentioned in the hadith above were in the process of learning how to practice Islam. They just entered the fold of Islam, which means that they were ignorant in many practices of Islam. In dealing with these two, Prophet Muhammad did not reprimand, use harsh words, criticize, making sarcastic remarks and he also did not punish or beat them. The Prophet's practice is contrary to the practices of many teachers in Malaysia including Islamic studies teachers (Wan Yusoff \& Mansor, 2014). Instead, Prophet Muhammad was very patient and gentle; and he never embarrassed anyone who made mistakes (al-Munajjid, 2008). This hadith can be applied to students since they are in the process of learning and acquiring new knowledge. The mistakes done by these two persons were not serious mistakes. Urinating and talking are part of being human but to urinate and talk at wrong place and time is wrong; and need to be corrected. Similarly, students are allowed to talk but it is wrong to talk while teacher is teaching. When dealing with common misbehaviors, teacher should be more patient and gentle; and avoid scolding, screaming at students, punishing or beating them.

The two hadith mentioned above revealed techniques that Prophet Muhammad used in handling misbehavior. If it is deemed necessary to wait for the wrongdoer to finish what he is doing, then wait before correcting his mistake. When correcting mistakes:

- Use precise words in just one or two sentences.

- Be general and do not specifically mention the wrongdoer's name or the word "you". This means the reminder 
or information is meant for all not just the wrongdoer.

- Clearly explain the rule of what is not allowed and what is allowed.

For exampe, to correct the mistake of a student who is talking while teacher is teaching, just say, "Students are not allowed to talk while teacher is teaching; teachers are to be respected, listened to and learned from."

\section{3 lgnoring Small Mistakes}

Anas ibn Malik reported: "A man came panting and entered the row of worshippers and said, 'Praise be to Allah, much praised and blessed.' When the Messenger of Allah (may peace be upon him) finished the prayer he said, 'Who amongst you uttered these words?' The people remained silent. He (the Holy Prophet) again said, 'Who amongst you uttered these words? He said nothing wrong.' Then a man said, 'I came panting, so I uttered them.' He replied, 'I saw twelve angels facing one another as to who will take those words up (to Allah)." Hadith number 1247 recorded by Imam Muslim.

Anas ibn Malik reported: "The Prophet was with one of his wives when another of Prophet wives sent a big vessel full of food to him. The wife in whose house the Prophet was struck the hand of the servant, and the vessel fell and broke into two pieces. The Prophet picked up the pieces and put them together, then he gathered up the food that had been in vessel and said, 'Your mother is jealous.' Then he asked the servant to wait and gave him a whole vessel belonging to the wife in whose house he was, and kept the broken vessel in the house of the one who had broken it." Hadith number 5225 recorded by Imam Bukhari.

Sometimes mistakes are best to be ignored and teacher should focus on good behaviors because human cannot run away from making mistakes. For those who make mistakes to gain attention of teachers, ignoring the person who make mistakes could solve this problem. The hadith above illustrate how a man came late for congregational prayer but he still was able to perform congregational prayer with the Prophet. He was so thankful that he uttered those words loud enough that people could heard him. Talking loudly while others were praying is another mistake done by this man. But The Prophet was not angry at the man and he did not reprimand or punish him for coming late to perform the prayer. Prophet ignored the mistakes done by this man and focus on the good words that the man has uttered. Similarly, when one of the Prophet's wives broke a bowl owned by his other wife, he just ignored the wife's misbehavior and focus on cleaning up the mess. However, the Prophet replaced the broken bowl to be fair.

Ignoring common mistakes and focus on good behavior has shown to motivate students to change from committing mistakes to practicing good behaviors (Wan Mazwati Wan Yusoff, 2012). In the above hadith, Prophet Muhammad mentioned specifically the good words that the man uttered and also the value or impact of those words.

This was done in public at the mosque among the well known and closed companions of the Prophet. Even though the hadith did not mention the Muslims who were praying at that time but it is common knowledge that Prophet's companions never missed congregational prayers at the mosque in Madinah. Therefore, when students made mistakes but at the same time performed good behaviour, teacher should focus on good behaviour and reinforce the good behavior by mentioning the positive value or impact of the good action.

\subsection{The techniques used by Prophet Muhammad in dealing with common mistakes are:}

- Ignore the mistakes done out off ignorance.

- Focus on the good behaviors.

- Reinforce the good behaviors, good effort, and good outcomes by mentioning specifically the good behaviors, effort and the outcomes of their effort.

- Mention the impact of the good behavior to the doer and others

- When the good behaviors were performed in public, mention them in public but avoid referring to the doer to stress on the actions not the person. In other words, do not praise the person but praise the good actions or outcomes. This may encourage others to emulate the good behavior. For instance, when a student answered all questions correctly, do not say, "You are clever" but say, "Good, your answers are correct".

\subsection{Giving Solution to Rectify Mistakes}

Abdullah Ibnu Mas'ud reported: "A person came to Allah's Apostle (may peace be upon him) and said, 'Allah's 
Messenger, I sported with a woman in the outskirts of Medina, and I have committed an offense short of fornication. Here I am (before you), kindly deliver verdict about me which you deem fit'. Umar said, 'Allah concealed your fault. You had better conceal it yourself also'. Allah's Apostle (may peace be upon him), however, gave no reply to him. The man stood up and went away and Allah's Apostle (may peace be upon him) sent a person after him to call him and he recited this verse, 'And observe prayer at the ends of the day and in the first hours of the night. Surely, good deeds take away evil deeds. That is a reminder for the mindful' (al-Qur'an, Hud: 114). A person amongst the people said, 'Allah's Apostle, does it concern this man only?' Thereupon he (the Holy Prophet) said, 'No, but the people at large'." Hadith number 6658, recorded by Imam Muslim.

Abu Hurairah reported: "A person came to the Apostle of Allah (may peace be upon him) and said, 'Messenger of Allah, I am doomed!' He (the Holy Prophet) said, 'What has brought about your ruin?' He said, 'I have had intercourse with my wife during the day in the month of Ramadan'. Upon this he (the Holy prophet) said, 'Can you find a slave to set him free?' He said, 'No'. He (the Holy Prophet again) said, 'Can you observe fast for two consecutive months?' He said, 'No'. He (the Holy Prophet) said, 'Can you provide food to sixty poor people?' He said, 'No'. He then sat down and (meanwhile) there was brought to the Apostle of Allah (may peace be upon him) a basket which contained dates. He (the Holy Prophet) said, 'Give these (dates) in charity'. He (the man) said, 'Am I to give to one who is poorer than I? There is no family poorer than mine between the two lava plains of Medina'. The Apostle of Allah (may peace be upon him) laughed so that his molar teeth became visible and said, 'Go and give it to your family to eat'." Hadith number 2457 reported by Imam Muslim.

Two men in the above hadith had committed serious mistakes according to Islamic codes of ethics. However, Prophet Muhammad was patient and compassionate when dealing with these wrongdoers. He did not pass judgement on them and called them sinners. He did not scold or punish them to teach them a lesson. From this hadith, it is apparent that Prophet Muhammad did not investigate or ask why these men committed such serious mistakes. Further, he did not want to know the woman who was involved with the man for probing for more information would certainly tarnish the good name of the woman's family. Anas ibn Malik said that, "I served the Apostle of Allah for nine years but he never said to me about a thing which I had done why I did that, or about a thing I had left as to why I had not done that" (Hadith number 5724 reported by Imam Muslim).

To deal with the misconduct, Prophet Muhammad suggested a solution for the man to do good deeds because good deeds cleansed the sins of evil deeds. As for the married man who had intercourse during the day in the month of Ramadan, Prophet Muhammad asked him to choose among three alternatives. Since the man said that he had no capability to do any of the alternatives, Prophet Muhammad gave him a basket of dates to be distributed to the poorest in Madinah. Since the man who had committed the serious mistakes was the poorest in Madinah, the dates were given to his family. This incident proved how compassion and sympathetic Prophet Muhammad was.

The application of these hadith is suitable in situation where students committed mistakes which do not involved public property and safety. The serious mistakes committed are personal. The important principles that could be extracted from these hadith are:

- Do not ask probing questions to investigate why students behave the way they do.

- Suggest possible solutions to help correct the mistakes done by students.

- Help students to perform one of the alternatives suggested to them.

Prophet Muhammad used various techniques to correct mistakes done by his companions and Muslims who live in his time. The strategies and techniques used by the Prophet were depended upon the context within which the misconduct were committed and the background of the individuals who committed the mistakes. However, only three methods of correcting misbehaviors were selected for this study. This study aim to validate the techniques used by Prophet Muhammad in correcting mistakes; whether they were effective to reduce classroom misbehaviors and met the criteria of good intervention program.

\section{Method of Study}

This qualitative research collected data through two one-hour semi-structured interview sessions with the teacher. One session was conducted at the teacher participant's home and another one at the researcher's place. The interviews were audio-taped and transcribed verbatim. The teacher participant had a bachelor degree in Islamic Shari'ah and arabic language was teaching Islamic Studies, reading and writing in Arabic alphabets and Arabic Language to primary five students in Kajang, Selangor. She has more than four years experience in practicing Prophet Muhammad's techniques in handling classroom misbehaviors. She was trained by the researchers in 2011 and was awarded as a certified 
practitioner and trainer by an authorized body which was given sole authority to train those who are interested in application of Prophet Muhammad's techniques in solving behavioral problems in various settings. The participant was asked to write a teacher's journal to record how she applied the techniques in details and her experiences, feelings, and observations of students' behavior prior to application, immediate effects right after application and after six months of continuous application of Prophet Muhammad's techniques. The journal was an important source of information to determine that the participant had applied the techniques correctly as trained to ascertain that the data was fit for analysis. Forty-two journal entries were collected for analysis. In addition, classroom artifacts such as video-recordings of selected classroom sessions and pictures of students during teaching and learning process were also collected for analysis. Since the aim of this study was to determine the effectiveness of the techniques used in handling classroom misbehaviors, the analysis of the data was guided by hypothetical categories. The frequently used and repeated words and phrases were coded and labeled under specific categories which were compared with the hypothetical categories. The same procedures were also done on the classroom artifacts.

\section{Findings}

The students involved in this study were 48 11-year old students from two classes of low achievers who went to a religious school located in Kajang, Selangor. Malaysian schools practice streaming students according to academic ability. Students in the last class were labeled as stupid, failures and had no future by school administrators, teachers and peers. The students who participated in this study had accepted the labels that were given to them. They displayed common characteristics of low achievers; they had low interest in learning indicated by poor engagement in classroom and low task interest; low self-esteem and had disciplinary problems such as high absenteeism. Students from these two classes were also labeled as the naughtiest and the most stubborn in the school. Some of them could not read and write Malay Language written in Arabic script, while some had difficulty in reading and writing in Malay Language in Arabic script. They had committed various common classroom misbehaviors such as disobeying teacher's instructions; disrespectful of teachers; making distracting noises; walking around in class or to friends desks; disturbing friends; coming late to class; talking while teachers were teaching; playing with friends while teachers were teaching; refusing to do or to complete tasks given by teachers; not interested in lessons; losing focus in teaching and learning processes; and sleeping in class. In terms of Islamic religious obligations, these students would performed their religious obligations after being reminded and some students would not perform their religious duties.

The teacher participant reported that she was given the low achievers' class on the day she reported for duty. She took this as a challenge and was thankful also for given an opportunity to practice Prophet Muhammad's techniques of promoting good behaviours and handling misbehaviours in classroom. Prior experiences in applying Prophet's methods made her confident to handle the given classes. However, the first day of school was nerve wrecking for her when she found a classroom full of students running around making loud noises and disturbing others. At that moment she felt she wanted to scream and scold those students, however she remembered the training in Prophet Muhammad's methods.

She took a deep breath and reminded herself to be sincere, patient, gentle, and compassionate like the Prophet. Before she entered the class, she decided to ignore the commotion without asking accusative questions and focus on good behaviors only; however mistakes which cannot be ignored must be dealt with by explaining the rules; and she was determined to provide as much assistance to her students to solve their learning and behavioral problems.

\subsection{Implementation in Classroom}

From the analysis of the collected data, it is confirmed that the teacher participant has become highly skilful in applying Prophet Muhammad's techniques of correcting mistakes. She had succeeded in applying the three methods explained this paper in primary school's classrooms. The first few weeks of class, the teacher would explain the rules of the class and also reminded the students of the school rules. This was done in conformity with the methods used by Prophet Muhammad.

The teacher explained, "The first few days of classes, I observed students were talking, playing with friends, disturbing others, and sleeping. I did not scold, punish, or argue with them. I was not angry at all. I ignored their mistakes and started to look at them one by one until they all stopped doing what they were doing. Then I explain to them the rules they had to follow. I said, "When teacher is ready to start a lesson, students are not allowed to do several things. First, Students are not allowed to talk while teacher is teaching except given permission by teacher. Teacher is to be respected, listened to, learn from. Second, classrooms are not the place for playing alone or with friends; 
classrooms are the place to learn new things. Third, disturbing friends are not allowed during lessons; pay full attention during lessons. Fourth, Sleeping is not allowed in the classroom. Classroom is a place to learn and experience new things'. Of course we cannot expect they would obey right away. They will still talk, play, sleep, do many other things but we must know what mistakes to ignore and what mistakes to correct".

Further, the teacher applied several techniques together to correct mistakes and to reinforce good behavior. She agreed, "Most of the time I ignore the common and insignificant mistakes like talking and making loud noises. As long as they completed the tasks given to them, I would ignore minor mistakes. For instance, I conducted my Qur'an memorization class at the school library. Students walked in lines but they were talking, laughing and making distracting noises along the way. However, they came early and right on time. I ignored their little mistakes and reinforce their good behavior. I said, 'Indeed I am happy, most of you came early and on time to class today. Allah like those who are punctual'. The students smiled and started to do their memorization and amazingly, the next day, more students came early to class".

When students made mistakes, the teacher did not investigate and ask them accusative questions, that is, why questions which appeared to be more of making accusation then asking for reasoning. She did not ask why you were late; why you did not finish your homework; why you disturb your friends; why you always cut school? But instead, she would offer to help the students. Instances of not asking probing question were plenty in the data. A few times, when students handed in incomplete homework or did not do their homework at all, she would not question the students, reprimand or punish them. Instead she would offer to help the students to complete their homework. The teacher said, "I would offer to help them by asking, 'Do you want if I help you with your homework?' Of course of majority of the students would answer in affirmative. Then, I would tell them to meet me at the teachers' room during break time where I guided them to finish their tasks".

\subsection{Effectiveness of the Techniques}

Analysis of the data revealed that the Prophet Muhammad's techniques of correcting mistakes were effective in reducing classroom misbehaviours when they were applied daily, that is, in every teaching and learning sessions; and outside the classroom whenever teacher has contact with students. However, the time taken to correct the misbehaviors varies according to types of misbehaviours and some common misbehaviors, teachers have to ignore and accept that human has certain personality traits that cannot be changed. For certain disruptive classroom behaviors, the impact of using the techniques was immediate. For example, at one time, the students were not motivated to learn because the majority of classes were cancelled. Most teachers and students were involved in a big school program. Other classes which were not involved continued lessons as usual. Students of this class tried to persuade the to cancelled the class and go home; and some were playing and running around the classroom. However, girls were sitting down, getting ready to start doing the task given by the teacher. The teacher ignored boys disruptive behaviors and made a positive comment on girls good behavior. She said, "Wow, Good! I am pleased that girls are starting to work. I am confident that they will finish their tasks in time. Since the girls obeyed their teacher, lets give them a big round of applause; and they gave a big round of applause for the girls...Amazingly, the boys walked to their desks and began to work on their tasks. Once again I praised their good behaviour the same way and asked all students to give themselves a big round of applause."

Before the teacher was trained in application of Prophet Muhammad's techniques, she was like any other teacher who use punitive methods to force students' compliance. She was convinced the techniques were effectives after she did few tests. After three weeks applying these techniques daily, she asked her students to hand in their homework the next day. Previously only three, sometimes four students would submit their homework. After experiencing positive changes in her students' behavior, she would expect one or two students would not finish their homework. She was surprised the next day when she found on her table, all students had submitted their assignment.

The teacher admitted that she was "really touched with the students changes, they were labeled as stupid and naughty. But after only few weeks of applying these techniques daily, there was no more incomplete tasks, both in class or homework; all of them were fully engaged in completing their class work; there was no more running around in class and playing; without asking, they would get into groups during Qur'an memorization class; amazingly, low achievers can collaborate well when they were given group work; they help each other to complete their tasks"..."and the best gift my students gave to me was they beat the first class in national examination when $100 \%$ of the students passed the exam". However, the students still talk in class and sometimes they made loud noises but they knew when to talk and make noises. 


\subsection{Ease of Preparation and Application}

After applying these techniques for few weeks, the teacher reported that she became quite skilful and spent less time to prepare before class. The time taken to prepare for application was between 30 minutes to one hour during the first week, after that the time spent decreased as the teacher become more skilful. After four years practicing Prophet Muhammad's methods, the teacher did not need to prepare at all. She has acquired the skills and become second nature to her. As for ease of application, the techniques were easy to apply however it required teachers to be patient, compassionate and sympathetic as well as sincere so that teachers would not revert to the old habit. With determination to see changes in students' negative behaviors, application would be easy. Applying these techniques only took about one or two minutes of class time. This means that these techniques would not disrupt the normal class activities.

"Applying the Prophet methods is nothing but changing your way of interacting with students. If we used to give negative comments, scold and punish change them to these techniques", said the teacher. Obviously, scolding and punishing students took up more class time than applying the Prophet's techniques. Finally, the investment to go for training in Prophet Muhammad's techniques of correcting mistakes was very minimal. The teacher spent less than USD35.00 to go for one full day training. The teacher further commented that she felt privileged for practicing and continuing the tradition of Prophet Muhammad. "To know that we hold on and practice teachings of the holy Prophet is emotionally and spiritually satisfying. As Muslims we must refer to our sources of knowledge to solve our problems", commented the teacher.

\section{Conclusion}

Studies have revealed that using punitive measures to deal with classroom misbehaviors were ineffective and may reinforce negative behaviors. Realizing that hadith provides empirical evidences of the effectiveness of Prophet Muhammad's methods and techniques of correcting misbehaviors, the researchers made rigorous analysis of hadith to discover principles and techniques for application in primary school classroom. This study aims to evaluate the effectiveness of the application of Prophet Muhammad's techniques in handling misbehaviors in primary school classrooms. From the analysis of six selected authentic hadith, four techniques of correcting mistakes were discovered. The techniques were dealing with mistakes by explaining the rules; ignoring small mistakes and reinforcing good behavior; rectifying problems by giving solutions; and avoiding asking investigative questions. Findings of this study revealed that the Prophet techniques were effective to reduce classroom misbehaviors; did not consume time for normal classroom activities; easy to prepare and apply; and parsimonious. To ease the application of these techniques, teacher should be sincere, patient, gentle, compassionate and sympathetic. Moreover, teachers should avoid negative criticism and harsh words, reprimand, punishment and making sarcastic remarks when dealing with student misbehaviors in the classroom.

This study provides literature for the relevantization project which is the mission of International Islamic University Malaysia. It may guide others who are interested in doing empirical research to provide evidences of relevancy of hadith for solving contemporary human problems and issues. The result of this study provide confidence for those who choose to refer to Islamic sources to provide solutions to their problems.

\section{References}

Angus, M., McDonald, T., Ormond, C., Rybarcyk, R., Taylor, A., \& Winterton, A. (2009). Trajectories of classroom behavior and academic progress: A study of student engagement with learning. Mount Lawley, Western Australia: Edith Cowen University.

Arbuckle, C. \& Little, E. (2004). Teachers' perceptions and management of classroom disruptive behavior during the middle years (year five to nine). Australian Journal of Educational and Developmental Psychology, 4, 59-70.

Bowen, J., Jensen, W., \& Clark, E. (2004). School based intervention for students with behavior problems. New York: Kluwer.

Brown, E. C., Catalano, R. F., Fleming, C. B., Haggerty, K. P., \& Abbott, R. D. (2005). Adolescent substance use outcomes in the Raising Healthy Children Project: A two part latent growth curve analysis. Journal of Consulting and Clinical Psychology, 73, 699-710.

al-Bukhari. Sahih Bukhari. Available at http://www.sahih-bukhari.com. Retrieved 1st March 2015.

Cholewa, B., Smith-Adcock, S., \& Amatea, E. (2010). Decreasing elementary school children's disruptive behaviors: A review of four evidence-based programs for school counselors. Journal of School Counseling, 8(4), 1-34.

Conduct Problem Prevention Research Group. (1999). Initial impact of the Fast Track prevention trial for conduct problem: 1. The highrisk sample. Journal Consulting and Clinical Psychology, 67, 631-647.

Conduct Problem Prevention Research Group. (2002). Evaluation of the first 3 years of the fast Track prevention trial with children at 
high risk for adolescent conduct problems. Journal of Abnormal Child Psychology, 30, 19-35.

Donaldson, J. M., Vollmer, T. R., Krous, T., Downs, S., \& Berard, K. P. (2011). An evaluation of the good behavior game in kindergarten classrooms. J Appl Behav Anal., 44(3), 605-609.

Gable, R., Hester, P., Rock, M., \& Hughes, K. (2009). Back to basics: Rules, praise, ignoring, and reprimand revisited. Intervention in School and Clinic, 44, 195-205.

Guardina, C. A., \& Fullerton, E. (2010). Changing behaviors by changing the classroom environment. Teaching Exceptional Children, 42(6), 8-13.

Hawkins, J. D. Kosterman, R., Catalano, R. Hill, K. G., \& Abbott, R. (2005). Promoting positif adult functioning through social development intervention in childhood: Long term effect from the Seattle Social Development Project. Archives of Pediatric and Adolescent Medicine, 159, 25-31.

Henly, M. (2010). Classroom management: A proactive approach. Upper Saddle River, NJ: Pearson.

Ibn Majah

Ibrahim Zein. (2012). Relevantization of Ulum al-Millah and its contribution to Islamization of human knowledge. Revelation and Sciences, 2(2), 1-17.

Kamal Hasan. (2009). The integration of human sciences and revealed knowledge in the KIRKHS. In Syed Arabi Idid (Ed.), IIUM at 25: The path travelled and the way forward. pp. 111-124. IIUM Press: Gombak, Kuala Lumpur.

Kellam, S. G., Brown, C. H., Poduska, J. M., Ialongo, N. S., Wang, W., \& Toyinbo, P. (2008). Effects of a universal classroom behavior management program in first and second grades on young adult behavior, psychiatric, and social outcomes. Drug and Alcohol Dependence, 95S, S5-S28.

Kellam, S. G., Mackenzie, A.C., Poduska, J. M., Wang, W., Petras, H., \& Wilcox, H. C. (20011). The Good Behavior Game and the future of prevention and treatment. Addiction Science \& Clinical Practice, July, 73-84.

Kerr, M. M. \& Nelson, C. M. (2010). Strategies for addressing behavior problems in the classroom. Upper Saddle River, NJ: Pearson.

Kohn, A. (2006). Beyond discipline: From compliance to community. Alexandria, VA: Association for Supervision and Curriculum Development.

Madsen, C. H., Becker, W. C. \& Thomas, D. R. (2001). Rules, praise, and ignoring: Elements of elementary classroom control. Journal of Direct Instruction, 1(1), 11-25.

Maguire, M. Ball, S., \& Braun, A. (2010). Behavior, classroom management and student control. Enacting policy in English secondary school. International Studies in Sociology of Education, 20(2), 153-170.

al-Munajjid, (2008). Prophet Muhammad's methods of correcting people's mistakes. Riyadh, Saudia: International Islamic Publishing House.

Muslim ibn al-Hajjaj. Sahih Muslim. Available at http://www.iium.edu.my/deed/hadith/muslim. Retrieved 1 March 2014.

Patterson, G., Reid, J., \& Dishion, T. (1992). Antisocial boys: A social interactional approach (Vol. 4). Eugene, OR: Castalia Publishing.

Pisacreta, J., Tincani, M., Connell, J. E., \& Axelrod, S. (2011). Increasing teachers' use of 1:1 praise to behavior correction ratio to decrease student disruption in general education classrooms. Behavioral Interventions, 26, 243-260.

Raby, R. (2010). The intraccies of power relations in discourses of secondary school discipline strategies. In Z. Millei, T.G. Griffiths \& R.J. Parkes (Eds.), Re-theorizing discipline in education: Problems, politics and possibilities (pp. 43-58). New York: Peter Lang Publishing Inc.

Rinke, W. M., \& Herman, K. C. (2002). Creating school environment that deter antisocial behaviors in youth, Psychology in the Schools, 39(5), 549-559.

Scott, S., Spender, Q., Doolan, M., Jacobs, B., \& Aspland, H. (2001). Multicenter controlled trial of parenting groups for child antisocial behavior in clinical practice. British Medical Journal, 323, 1-5.

Sullivan, A.M., Johnson, B., Owens, L., \& Conway, R. (2014). Punish or engage them? Teachers' views of unproductive student behaviors in the classroom. Australian Journal of Teacher Education, 9(6), 43-57.

Slee, R. (1995). Changing theories and practices. London: The Falmer Press.

Thompson, B. (2009). Disruptive behaviors in Barbadian Classroom: Implication for universal secondary education in the Caribbean. Journal of Eastern Caribbean Studies, 34(3), 39-58.

Wakschlag, L., Leventhal, B., Briggs-Gowen, M., Danis, B., Keenan, K., \& Hill, C. (2005). Defining the 'disruptive' in preschool behavior: What diagnostic observation can teach us. Clinical Child and Family Psychology Review, 8, 183-201.

Wan Mazwati Wan Yusoff. (2012). The impact of Prophet Muhammad's motivation techniques on students' performance. ProcediaSocial and Behavioral Sciences, 69, 1700-1708.

Way, S. M. (2011). School discipline and disruptive classroom behavior: The moderating effects of student perceptions. The Sociological Quarterly, 52, 346-375.

Wan Yusoff, W. M., \& Mansor, N. (2014). Exploring the effectiveness of strategies used in managing classroom disruptive behaviors. ICERI2014 Proceedings, pp. 2522-2530.

Webster-Stratton, C. \& Reid, M. J. (2004). Strengthening social and emotional competence in young children-the foundation in early school readiness and success: Incredible years classroom social skills and problem solving curriculum. Journal of Infant and Young Children, 17, 96-113.

Wheeler, J. J. \& Richey, D. D. (2010). Behavior management: Principles and practices of positive behavior supports (2nd edn.). Upper Saddle NJ: Pearson. 
ISSN 2239-978X

ISSN 2240-0524
Journal of Educational and Social Research MCSER Publishing, Rome-Italy
Vol. 5 No.1 S1 April 2015 